\title{
An integrated, dynamic model of feed hydration and digestion, and subsequent bacterial mass accumulation in the rumen
}

\author{
BY JAAP VAN MILGEN*, LARRY L. BERGER† AND MICHAEL R. MURPHY \\ Department of Animal Sciences, University of Illinois, Urbana, Illinois 61801, USA
}

(Received 12 November 1991 - Accepted 20 October 1992)

\begin{abstract}
Hydration of feeds and bacterial attachment to feed particles are thought to play major roles in rumen digestion of fibrous feedstuffs. The objective of the present study was to integrate these phenomena in a mechanistic model that could be used for data analysis. The proposed model was based on the conversion of biomass, where digestion end-products can be used for the synthesis of bacterial mass. Digestion of the potentially digestible fraction and subsequent accumulation of bacterial mass was based on a sequential, three-compartment model. These compartments represented substrate undergoing hydration, digestion, and bacterial mass accumulation. A fraction of the substrate was used for synthesis of bacterial mass. It was assumed that these bacteria associate either temporarily or permanently with the remaining substrate. Dacron bags containing either dry or fully-hydrated lucerne (Medicago sativa), maize (Zea mays) cobs, orchard grass (Dactylis glomerata), and wheat straw were incubated in the rumen of a steer that was infused continuously with $\left({ }^{15} \mathrm{NH}_{4}\right)_{2} \mathrm{SO}_{4}$. The ${ }^{15} \mathrm{~N}$-enrichments of isolated particle-associated bacteria and residue remaining in the bags were used to estimate bacterial attachment. Substrate remaining and microbial mass accumulation were analysed simultaneously. Hydration did not appear to limit digestion. Fractional rate of digestion and appearance of attached bacterial mass was fastest for lucerne. For lucerne, $5 \%$ of the digestion end-products were used for synthesis of bacteria that associated with the substrate, whereas for maize cobs, orchard grass, and wheat straw this was 16,14 , and $19 \%$ respectively. Less than $2 \%$ of digestion end-products were used for synthesis of bacteria that permanently remained associated with the substrate. Permanent association can occur only with the indigestible fraction, and probably represents bacterial debris. Lysis and/or detachment of bacterial cells was highest for lucerne, and was indicative of the rapid dynamics of lucerne digestion.
\end{abstract}

Models: Bacterial attachment: Rumen digestion

Fibrous feedstuffs play an important role in ruminant nutrition. Digestion of these feeds primarily occurs in the rumen and is mediated through microbial enzymes which may be cell-bound. Therefore, attachment of rumen microbes to feed particles is thought to be a critical phase of digestion. As a result, the residue of incubated feedstuffs can contain considerable quantities of microbial mass (Olubobokun \& Craig, 1990). Thus far, research in this field has focused primarily on the need to correct for this 'contamination' when estimating rumen digestion variables. Although attempts have been made to model microbial attachment to feed particles (Nocek \& Grant, 1987), these models have been empirical in design. Empirical models generally lack the ability to explain the data; they merely redescribe it (Thornley \& France, 1984). In contrast, mechanistic models try to explain the observed data using a description of phenomena at a lower level of aggregation.

* Present address: Institut National de la Recherche Agronomique, Centre de Clermont-Ferrand Theix, 63122 Ceyrat, France.

$\uparrow$ For reprints. 
For example, microbial contamination is a function of microbial mass accumulation and substrate remaining:

$$
\text { microbial contamination }(\%)=\frac{\text { microbial mass } \times 100}{\text { microbial mass }+ \text { substrate remaining }} .
$$

Also, accumulation of microbial mass and digestion of substrate are not independent processes. Microbial mass is synthesized in the rumen either directly or indirectly from digestion of substrate. The objective of the present study was to develop a mechanistic model that would integrate these processes, and that could be used for data analysis.

\section{MATERIALS AND METHODS}

\section{Substrate preparation}

Lucerne (Medicago sativa), maize (Zea mays) cobs, orchard grass (Dactylis glomerata), and wheat straw were ground through a $4 \mathrm{~mm}$ screen and samples (approximately $4 \mathrm{~g}$ ) were weighed into 272 multifilament, dacron bags $(70 \times 130 \mathrm{~mm}$, pore size $50 \mu \mathrm{m})$. Half the bags were stored dry at $4^{\circ}$ (dry substrate); the other half were incubated in 201 saline $(9 \mathrm{~g}$ $\mathrm{NaCl} / 1$ ) at $4^{\circ}$ for $7 \mathrm{~d}$ (hydrated substrate). To avoid bacterial contamination, saline was replaced daily. Following this hydration period, excess water was removed by draining the bags.

\section{Animal and management}

A mature, Jersey steer $(530 \mathrm{~kg})$ was fitted with a rumen cannula according to procedures approved by the Campus Laboratory Animal Care Committee at the University of Illinois. The steer was housed in a continuously-lighted, temperature-controlled room $\left(20^{\circ}\right)$ and fed on a chopped, mixed-forage diet twelve times daily $(7200 \mathrm{~g} / \mathrm{d})$ at $2 \mathrm{~h}$ intervals using an automatic feeding system. The chemical composition of feed and substrates is given in Table 1. Water and a trace mineral salt block were available ad lib.

At $7 \mathrm{~d}$ before incubation of the bags the steer was ruminally pulse-dosed with 21 $26.5 \mathrm{~mm}-\left({ }^{15} \mathrm{NH}_{4}\right)_{2} \mathrm{SO}_{4}$ (containing $10 \cdot 3$ atom $\%{ }^{15} \mathrm{~N}$ ). This pulse dose was based on an assumed ${ }^{15} \mathrm{~N}$ rumen turnover time of $1 \mathrm{~d}$. During the remainder of the experiment, $26.5 \mathrm{~mm}-\left({ }^{15} \mathrm{NH}_{4}\right)_{2} \mathrm{SO}_{4}$ was infused continuously at a rate of $21 / \mathrm{d}$ using a peristaltic pump. At $1 \mathrm{~d}$ before incubation of the bags, the steer was pulse-dosed with Co-EDTA (860 mg Co; Udén et al. 1980).

\section{Sample collection and analysis}

Sets of sixteen dacron bags (four substrates, two hydration states, two replicates per time point) were put into loose-mesh sacks which were anchored with a weight. Sacks were incubated below the particulate mat layer in the rumen for $0.5,1,1.5,2,3,4,6,9,13$, $18,24,31,40,54,77$ and $154 \mathrm{~h}$. Eight sacks (for $0.5-9 \mathrm{~h}$ ) were incubated at 08.00 hours, whereas the remaining sacks (for $13-154 \mathrm{~h}$ ) were incubated at 20.00 hours. After incubation, dacron bags were washed with cold tap water and frozen. Bags for zero time were not incubated in the rumen but underwent the same rinsing procedures as bags that were incubated. Following completion of the experiment, bags were thawed, washed with cold water in a two-cycle washing machine and dried at $57^{\circ}$. The residue was analysed for dry matter (DM; Association of Official Analytical Chemists, 1984), N (Bremner \& Mulvaney, 1982) and ${ }^{15} \mathrm{~N}$-enrichment (Mulvaney et al. 1990).

Each day, before a feed, a sample of rumen fluid was collected and the $\mathrm{pH}$ was measured. Rumen fluid $(50 \mathrm{ml})$ was acidified with $3 \mathrm{M}-\mathrm{HCl}$ and frozen. Samples were later thawed and analysed for $\mathrm{NH}_{3}-\mathrm{N}$ and ${ }^{15} \mathrm{NH}_{3}$-enrichment (Cecava et al. 1991). After removal of the last bags from the rumen, $1 \cdot 5$ litres rumen contents were collected using a core sampling device 
Table 1. Composition ( $\mathrm{g} / \mathrm{kg}$ dry matter) of feed and substrates

\begin{tabular}{|c|c|c|c|c|c|}
\hline Item & Feed* & $\begin{array}{c}\text { Lucerne } \\
\text { (Medicago sativa) }\end{array}$ & $\begin{array}{c}\text { Maize } \\
\text { (Zea mays) } \\
\text { cobs }\end{array}$ & $\begin{array}{c}\text { Orchard grass } \\
\text { (Dactylis } \\
\text { glomerata) }\end{array}$ & Wheat straw \\
\hline OM & 912 & 903 & 978 & 891 & 905 \\
\hline $\mathrm{CP}$ & 88 & 215 & 30 & 106 & 54 \\
\hline $\mathrm{NDF}$ & 752 & 565 & 945 & 789 & 836 \\
\hline $\mathrm{ADF}$ & 517 & 456 & 479 & 487 & 586 \\
\hline $\mathrm{ADL}$ & 132 & 87 & 90 & 82 & 107 \\
\hline
\end{tabular}

* Contains $(\mathrm{g} / \mathrm{kg}):$ lucerne 210 , maize cobs 210 , orchard grass 290 , wheat straw 290 (ingredients differed in composition from substrates).

OM, organic matter (Association of Official Analytical Chemists, 1984); CP, crude protein (Bremner \& Mulvaney, 1982); NDF, neutral-detergent fibre (Goering \& Van Soest, 1975); ADF, acid-detergent fibre (Goering \& Van Soest, 1975); ADL, acid-detergent lignin (Goering \& Van Soest, 1975).

(Firkins et al. 1986). Fluid-associated (FAB) and particle-associated bacteria (PAB) were isolated as described by Cecava et al. (1990). Bacterial samples were analysed for DM, N, and ${ }^{15} \mathrm{~N}$-enrichment as described previously. It was assumed that the composition of PAB was identical to that of bacteria attached to substrate, and that this composition did not change with duration of incubation period. Bacterial DM content of the residue was calculated as ${ }^{15} \mathrm{~N}$ content of the residue (i.e. $\mathrm{N}$ content $\times{ }^{15} \mathrm{~N}$-enrichment): ${ }^{15} \mathrm{~N}$ content of PAB. Bacterial mass (g DM bacteria/g incubated substrate) and substrate remaining (g DM substrate/g incubated substrate) were calculated from the residue remaining and the bacterial content of this residue.

Core samples of rumen contents were collected at 1, 2, 3, 4, 6, 9, 13, 18, 24, 31, 40, 54, 77, and $154 \mathrm{~h}$ after Co-EDTA dosage. The fluid fraction was separated from the particulate fraction by squeezing the samples through four layers of cheesecloth. The fluid fractions were analysed for Co (Udén et al. 1980). Change in marker concentration with time was analysed as a first-order process using the NLIN procedure of SAS Institute Inc. $(1988 \mathrm{a})$ :

$$
\text { marker }=A_{0} e^{-k_{p} \text { time }}
$$

where marker is the marker concentration $(\mathrm{mg} / \mathrm{l}), A_{0}$ the initial marker concentration $(\mu \mathrm{g} / \mathrm{l})$, and $k_{p}$ the fractional liquid passage rate $(\mathrm{mg} / \mathrm{l})$. Rumen volume (litres) was calculated as $(\mathrm{mg} / \mathrm{l})$ the weight of the dosed marker $(\mathrm{mg}): A_{0}$.

\section{Models for digestion and bacterial mass accumulation}

Several workers have noted that samples obtained from in situ incubation studies could be contaminated with microbial cells (Nocek \& Grant, 1987; Olubobokun et al. 1990). Contamination of the substrate depends on both microbial mass accumulation and substrate disappearance. Models describing digestion usually contain one or more firstorder processes (Van Milgen et al. 1991). Therefore, it is unlikely that the microbial content of residues can be described by linear or quadratic models. In order to describe contamination adequately, the 'known' (digestion) and 'unknown' (microbial mass accumulation) processes have to be distinguished. The approach employed in the current study was that all bacterial mass originates from the substrate they attach to. The importance of this biomass conversion has been pointed out by Cheng et al. (1980) and simulation models based on this concept have been described by Papageorgakopoulou \& Maier (1984).

The proposed model assumed that the accumulation of bacterial mass on substrate 


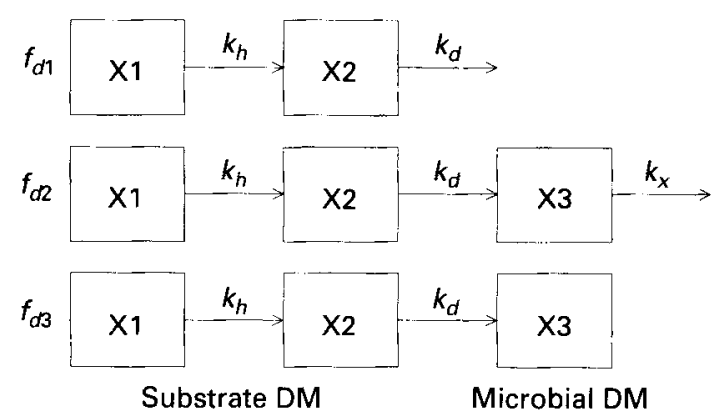

Fig. 1. Proposed model for digestion of potentially digestible substrate and bacterial mass accumulation in the rumen. X1, substrate undergoing hydration; $X 2$, substrate undergoing digestion; X3, microbial mass accumulation; $f_{a 1}$, potentially digestible fraction that results in the formation of digestion end-products that do not remain associated with the substrate; $f_{d 2}$, potentially digestible fraction that results in the formation of digestion end-products that temporarily remain associated with the substrate; $f_{d 3}$, potentially digestible fraction that results in the formation of digestion end-products that permanently remain associated with the substrate; $k_{h}$, fractional rate of hydration; $k_{d}$, fractional rate of digestion; $k_{x}$, fractional rate of bacterial detachment and/or cell lysis; DM, dry matter.

occurred during two phases. During the first phase, which might be mediated through chemotaxis, FAB adhere to intact substrate. Once attached, these now PAB will digest substrate and end-products of this digestion will be used for cell growth and microcolony formation. It is assumed that the mass of the adhering FAB is negligible compared with the mass of the microcolonies they produce. Individual bacteria from a microcolony will detach and adhere to other (parts of) particles. Microcolony formation will continue as long as there is digestible substrate. Once all potentially digestible substrate is digested, bacterial cells either detach or lyse. As the indigestible fraction is associated with the potentially digestible fraction, it is likely that cellular debris from lysed cells remains associated with the former.

The potentially digestible fraction $\left(f_{d} ; \mathrm{g} / \mathrm{g}\right.$ incubated) was partitioned into three subfractions based on the association of digestion end-products with the remaining substrate. Digestion of $f_{d}$ will result in the formation of end-products that are released into the medium and, therefore, are not associated with the remaining substrate $\left(f_{d 1}\right.$; e.g. volatile fatty acids). It was assumed that end-products which associate with the remaining substrate represent bacterial mass, and that this association can be either temporary $\left(f_{d 2}\right.$; e.g. bacterial cells) or permanent $\left(f_{d 3}\right.$; e.g. bacterial debris).

Digestion of the potentially digestible fraction and subsequent bacterial mass accumulation was based on a sequential, three-compartment model (Fig. 1). These compartments represented substrate undergoing hydration (X1), substrate undergoing digestion (X2), and bacterial mass accumulation on the substrate (X3). Both fractional rate of hydration $\left(k_{h} / \mathrm{h}\right)$ and fractional rate of digestion $\left(k_{d} / \mathrm{h}\right)$ were assumed to be identical for the three subfractions of $f_{d}$. Bacterial detachment and/or cell lysis were assumed to occur according to a single fractional rate $\left(k_{x} / \mathrm{h}\right)$. In order to keep the model as simple as possible, only hydration was assumed to delay disappearance of substrate. Other factors (e.g. initial attachment) might affect disappearance as well, but were not included in the model.

Fluxes of substrate digestion and bacterial mass accumulation were interpreted as net fluxes. For example, bacterial mass accumulation was based on ${ }^{15} \mathrm{~N}$ which was infused ruminally and, thus, did not originate from the substrate. This means that fractional rateconstants also should be interpreted as net fractional rate-constants, where the uptake of exogenous compounds by attached bacteria is compensated for by digestion of an equal amount of substrate. 
The system depicted in Fig. 1 actually is composed of three sub-systems. For dry substrate, all X2 and X 3 compartments initially are empty, whereas X1 contains $f_{d 1}, f_{d 2}$, and $f_{d 3}$ for the respective sub-systems. The sub-systems for $f_{d 1}$ and $f_{d 2}$ are open (i.e. have output), whereas the sub-system for $f_{d 3}$ is closed. Generalized equations for compartmental models are given by France et al. (1985). Substrate remaining for dry substrate is represented as the sum of the first two compartments plus an indigestible fraction $\left(f_{i} ; \mathrm{g} / \mathrm{g}\right.$ incubated), whereas bacterial mass accumulation is represented as the sum of the third compartments :

$$
\begin{aligned}
\text { substrate }(\mathrm{dry}) & =f_{d}(\mathrm{X} 1+\mathrm{X} 2)+f_{i}, \\
\text { bacterial mass }(\mathrm{dry}) & =f_{d 2} \mathrm{X} 3+f_{d 3}(1-\mathrm{X} 1-\mathrm{X} 2),
\end{aligned}
$$

where:

$$
\begin{gathered}
f_{d}=f_{d 1}+f_{d 2}+f_{d 3}, \\
\mathrm{X} 1=e^{-k_{h} \text { time }}, \\
\mathrm{X} 2=k_{h}\left(\frac{e^{-k_{h} \text { time }}}{k_{d}-k_{h}}+\frac{e^{-k_{d} \text { time }}}{k_{h}-k_{d}}\right), \\
\mathrm{X} 3=k_{h} k_{d}\left(\frac{e^{-k_{h} \mathrm{time}}}{\left.k_{d}-k_{h}\right)\left(k_{x}-k_{h}\right)}+\frac{e^{-k_{d} \mathrm{time}}}{\left(k_{h}-k_{d}\right)\left(k_{x}-k_{d}\right)}+\frac{e^{-k_{x} \mathrm{time}}}{\left(k_{h}-k_{x}\right)\left(k_{d}-k_{x}\right)}\right) .
\end{gathered}
$$

Digestion of dry and fully hydrated substrate was assumed to be identical with the exception of hydration. If it is assumed that hydration was completed for hydrated substrate (i.e. $k_{h}=\infty / \mathrm{h}$ ), substrate disappearance and bacterial mass accumulation for hydrated substrate can be described by a two-compartment system (i.e. the system depicted in Fig. 1 involving X2 and X3 only). Equations describing digestion and bacterial mass accumulation were adjusted accordingly.

Substrate DM remaining for both dry and hydrated substrates were analysed using the NLIN procedure of SAS Institute Inc. (1988a), assuming existence of three and two compartments respectively. Estimate parameters were compared using a $t$ test (Ratkowsky, 1983). The soluble fraction $\left(f_{s} ; \mathrm{g} / \mathrm{g}\right.$ incubated) was calculated as $1-f_{d}-f_{i}$, whereas the calculation of its asymptotic standard error was based on the covariance matrix of parameter estimates. A major disadvantage of this analysis procedure (referred to as individual analysis) is that it does not account for the (proposed) relationships that exist between digestion profiles. For example, estimates for $k_{d}$ could be different between dry and hydrated substrate, even though the proposed difference involves hydration $\left(k_{h}\right)$ only. Alternatively, a model can be constructed involving all four dependent variables (substrate remaining and bacterial mass accumulation for both dry and hydrated substrate) where the proposed relationship is incorporated in the model (referred to as simultaneous analysis). All dependent variables are analysed simultaneously using weighted least-squares regression. This type of analysis has been used before based on explicit expressions (Van Milgen et al. 1992) or differential equations for the dependent variables (Baldwin et al. 1990). Simultaneous estimation of parameters from substrate and bacterial mass profiles was done using the MODEL procedure of SAS Institute Inc. $(1988 \mathrm{~b})$. In order to analyse substrate and bacterial mass profiles simultaneously, data of the latter were standardized towards substrate data. For each substrate the standardizing factor was based on the standard deviation ratio between remaining substrate and bacterial mass:

$$
\text { standardizing factor }=\frac{\left(\frac{s_{\text {substratedry }}}{s_{\text {bacterial mass dry }}}\right)+\left(\frac{s_{\text {substrate hydrated }}}{s_{\text {bacterial mass hydrated }}}\right)}{2} \text {. }
$$


This procedure is similar to using weighted least squares where the weight is equal to the squared standardizing factor (Draper \& Smith, 1981).

\section{Functional specific gravity ( $F S G$ ) of substrates}

FSG of substrate DM was measured using procedures described by Hooper \& Welch (1985). A modified McDougall's buffer (bicarbonate was replaced by phosphate) was used as displacement solution. Samples (approximately $1.5 \mathrm{~g}$ ) were weighed into $50 \mathrm{ml}$ pycnometers and incubated with $35 \mathrm{ml}$ displacement solution at $39^{\circ}$ for $0,0 \cdot 5,1,1.5,2,3,4,6,9,13,18$, $24,31,40,54,77$, and $154 \mathrm{~h}$. After incubation, displacement solution $\left(39^{\circ}\right)$ was added to fill the pycnometers completely, after which they were weighed. The weight of pycnometers filled with displacement solution or water only was recorded as well. The FSG was calculated as:

$$
\mathrm{FSG}=\frac{W_{x} f_{D M} S G_{d}}{W_{\mathrm{z}}-\left(W_{1}-W_{x}\right)-W_{x}\left(1-f_{D M}\right) \bar{S} G_{a}}
$$

where $W_{x}$ is the sample weight $(\mathrm{g}), f_{D M}$ is the proportion of DM in the sample, $S G_{d}$ is the specific gravity of the displacement solution, $W_{2}$ is the weight of the displacement solution to fill the pycnometers $(\mathrm{g})$, and $W_{1}$ is the weight of sample plus displacement solution to fill the pycnometers $(\mathrm{g}) . S G_{d}$ was calculated as the weight ratio between displacement solution and water to fill the pycnometers. The equation used by Hooper \& Welch (1985) incorrectly uses the weight of water rather than the weight of the displacement solution in the denominator. Moreover, the proposed equation accounts for the volume of water in the sample. Change in FSG with time was described using a first-order model:

$$
\mathrm{FSG}=A\left(1-B e^{-k_{F} S G} \mathrm{time}^{\mathrm{tin}}\right)
$$

where $A$ is the asymptotic FSG, $B$ the potential change in FSG (i.e. asymptotic FSG minus initial FSG), and $k_{F S G}$ the fractional rate of change in FSG $(/ \mathrm{h})$. Parameters were estimated using the NLIN procedure of SAS Institute Inc. (1988a).

\section{RESULTS}

\section{Rumen characteristics}

During the experimental period, average rumen $\mathrm{pH}$ and $\mathrm{NH}_{3}$ concentration were 6.6 (SD 0.2) and 57 (SD 14) mg/l respectively. As neither an increase nor decrease of ${ }^{15} \mathrm{NH}_{3}$ enrichment was apparent during the infusion period, steady-state conditions were approached within $24 \mathrm{~h} .{ }^{15} \mathrm{~N}$-enrichment for $\mathrm{NH}_{3}$ averaged $0 \cdot 170(\mathrm{sD} 0 \cdot 031) \%$-excess ${ }^{15} \mathrm{~N}$ and was only slightly higher than ${ }^{15} \mathrm{~N}$-enrichment for PAB $\left(0 \cdot 168 \%\right.$-excess $\left.{ }^{15} \mathrm{~N}\right)$ and FAB $\left(0 \cdot 161 \%\right.$-excess $\left.{ }^{15} \mathrm{~N}\right)$. Rumen fluid volume and fractional fluid passage rate were $50 \cdot 0$ (asymptotic SE $1 \cdot 0$ ) litres and $0 \cdot 120$ (asymptotic SE $0 \cdot 005$ )/ h respectively.

\section{Substrate disappearance and bacterial mass accumulation}

Table 2 presents parameter estimates of variables when profiles for substrate disappearance were analysed individually (one dependent variable per analysis). With the exception of maize cobs, estimates were not different between dry and hydrated substrate. Parameter estimates were obtained simultaneously for substrate disappearance and bacterial mass accumulation for both dry and hydrated substrate (four dependent variables per analysis; Table 3). In general, parameter estimates obtained from simultaneous estimation of the profiles were intermediate to those obtained from individual analysis of the digestion profiles. For all four substrates a large proportion of $f_{d}$ resulted in the formation of endproducts that did not remain associated with the remaining substrate $\left(f_{a 1}\right)$. For lucerne this 
Table 2. Kinetic parameter estimates for dry and hydrated substrate obtained through individual analysis of substrate disappearance profiles ${ }^{\dagger}$

(Non-linear estimates and their asymptotic standard errors)

\begin{tabular}{|c|c|c|c|c|c|}
\hline & \multicolumn{2}{|c|}{ Dry substrate } & \multicolumn{2}{|c|}{ Hydrated substrate } & \multirow{2}{*}{$\begin{array}{c}\text { Statistical } \\
\text { significance } \\
\text { of difference }\end{array}$} \\
\hline & Estimate & $\mathrm{SE}$ & Estimate & $\mathrm{SE}$ & \\
\hline \multicolumn{6}{|c|}{ Lucerne (Medicago sativa) } \\
\hline$f_{d}$ & $0 \cdot 448$ & $0 \cdot 012$ & 0.467 & $0 \cdot 011$ & NS \\
\hline$f_{i}$ & $0 \cdot 224$ & 0.009 & 0.204 & 0.009 & NS \\
\hline$f_{s}$ & $0 \cdot 327$ & $0 \cdot 007$ & $0 \cdot 329$ & 0.009 & NS \\
\hline$k_{d}^{s}$ & $0 \cdot 071$ & $0 \cdot 008$ & 0.089 & 0.007 & NS \\
\hline$k_{h}^{a}$ & $0-415$ & $0 \cdot 165$ & & & \\
\hline \multicolumn{6}{|c|}{ Maize (Zea mays) cobs } \\
\hline$f_{a}$ & 0.690 & 0.013 & $0 \cdot 769$ & 0.025 & $* *$ \\
\hline$f_{i}^{f d}$ & $0 \cdot 220$ & 0.013 & $0 \cdot 163$ & 0.026 & NS \\
\hline$f_{s}$ & 0.090 & $0 \cdot 004$ & $0 \cdot 068$ & 0.008 & $*$ \\
\hline$k_{d}$ & 0.032 & 0.004 & 0.021 & 0.002 & $* *$ \\
\hline$k_{h}^{a}$ & 0.097 & 0.019 & & & \\
\hline \multicolumn{6}{|c|}{ Orchard grass (Dactylis glomerata) } \\
\hline$f_{a}$ & 0.609 & 0.016 & 0.629 & 0.012 & NS \\
\hline$f_{i}$ & $0 \cdot 226$ & 0.014 & $0 \cdot 209$ & 0.012 & NS \\
\hline$f_{s}$ & $0 \cdot 165$ & $0 \cdot 006$ & $0 \cdot 162$ & 0.005 & NS \\
\hline$k_{d}$ & 0.034 & 0.003 & 0.030 & 0.001 & NS \\
\hline$k_{n}^{a}$ & $0 \cdot 297$ & $0 \cdot 107$ & & & \\
\hline \multicolumn{6}{|c|}{ Wheat straw } \\
\hline$f_{d}$ & 0.566 & $0 \cdot 023$ & $0-523$ & 0.014 & NS \\
\hline$f_{i}^{a}$ & $0 \cdot 312$ & 0.024 & $0 \cdot 363$ & 0.015 & NS \\
\hline$f_{s}$ & $0 \cdot 122$ & $0 \cdot 005$ & $0 \cdot 115$ & 0.004 & NS \\
\hline$k_{\alpha}$ & $0 \cdot 015$ & 0.001 & 0.018 & 0.001 & NS \\
\hline$k_{h}$ & $\infty$ & & & & \\
\hline
\end{tabular}

NS, not significant $(P>0.05) ; f_{d}$, potentially digestible fraction $(\mathrm{g} / \mathrm{g}$ incubated $) ; f_{i}$, indigestible fraction $(\mathrm{g} / \mathrm{g}$ incubated); $f_{s}$, soluble fraction $\left(\mathrm{g} / \mathrm{g}\right.$ incubated); $k_{d}$, fractional digestion rate-constant $(/ \mathrm{h}) ; k_{h}$, fractional hydration rate-constant $(/ \mathrm{h})$.

${ }^{*} P<0.05, * * P<0.01$.

$\dagger$ For details of substrates and procedures, see Table 1 and pp. $472-476$

amounted to almost $95 \%$. Only $4.3 \%$ of $f_{d}$ was used for the synthesis of temporarily associated bacteria for lucerne $\left(f_{d 2}\right)$, compared with more than $12 \%$ for the other three substrates. Less than $2 \%$ of $f_{d}$ was used for the synthesis of permanently associated bacteria $\left(f_{d 3}\right)$.

Hydration appeared the least rate-limiting step in the proposed digestion process. For both orchard grass and wheat straw, fractional rate of hydration $\left(k_{h}\right)$ approached infinity $\left(>1 \times 10^{10} / \mathrm{h}\right)$. Fractional rates of digestion $\left(k_{d}\right)$ and detachment and/or lysis $\left(k_{x}\right)$ were highest for lucerne, followed by orchard grass.

Fig. 2 illustrates the fit of the model to the data. The axes are chosen so that the scale ratio between left (substrate remaining) and right (bacterial mass) $Y$-axis reflects the standardizing factor. Bacterial mass accumulates more rapidly, but to a lesser extent, for lucerne and orchard grass compared with maize cobs and wheat straw. For maize cobs and wheat straw, disappearance of substrate and bacterial mass accumulation did not approach completion within the time frame of the experiment $(154 \mathrm{~h})$. 
Table 3. Kinetic variables obtained through simultaneous analysis of substrate disappearance and bacterial mass accumulation profiles*

(Non-linear estimates and their asymptotic standard errors)

\begin{tabular}{|c|c|c|c|c|c|c|c|c|}
\hline & \multicolumn{2}{|c|}{$\begin{array}{c}\text { Lucerne } \\
\text { (Medicago sativa) }\end{array}$} & \multicolumn{2}{|c|}{$\begin{array}{c}\text { Maize } \\
(\text { Zea mays }) \text { cobs }\end{array}$} & \multicolumn{2}{|c|}{$\begin{array}{c}\text { Orchard grass } \\
\text { (Dactylis glomerata) }\end{array}$} & \multicolumn{2}{|c|}{ Wheat straw } \\
\hline & Estimate & SE & Estimate & SE & Estimate & SE & Estimate & $\mathrm{SE}$ \\
\hline$f_{d 1}$ & 0.436 & 0.011 & 0.635 & $0 \cdot 013$ & 0.550 & 0.010 & 0.437 & 0.010 \\
\hline$f_{d 2}$ & 0.020 & 0.003 & $0 \cdot 111$ & 0.007 & 0.079 & 0.006 & 0.093 & 0.007 \\
\hline$f_{d 3}$ & 0.005 & 0.000 & 0.010 & 0.006 & 0.010 & 0.001 & 0.011 & 0.003 \\
\hline$f_{d}$ & 0.462 & 0010 & 0.756 & 0.015 & 0.639 & 0.010 & 0.541 & 0.013 \\
\hline$f_{i}^{a}$ & $0 \cdot 215$ & 0.008 & $0 \cdot 172$ & 0.015 & 0.209 & 0.010 & $0 \cdot 340$ & 0.014 \\
\hline$f_{s}$ & 0.323 & 0.008 & 0.073 & 0.005 & 0.153 & 0.004 & $0 \cdot 120$ & 0.003 \\
\hline$k_{h}$ & 1.013 & 0.289 & 0.480 & $0 \cdot 119$ & $\infty$ & & $\infty$ & \\
\hline$k_{d}^{n}$ & 0077 & 0.006 & 0.021 & 0.001 & 0.029 & 0.001 & 0.016 & 0.001 \\
\hline$k_{x}$ & 0.161 & 0.028 & $0 \cdot 020$ & 0.004 & 0.065 & 0.007 & 0.027 & 0.004 \\
\hline
\end{tabular}

$f_{d 1}$, potentially digestible fraction that results in the formation of digestion end-products that do not remain associated with the substrate $\left(\mathrm{g} / \mathrm{g}\right.$ incubated); $f_{d 2}$, potentially digestible fraction that results in the formation of digestion end-products that temporarily remain associated with the substrate $\left(\mathrm{g} / \mathrm{g}\right.$ incubated); $f_{d 3}$, potentially digestible fraction that results in the formation of digestion end-products that permanently remain associated with the substrate $(\mathrm{g} / \mathrm{g}$ incubated $) ; f_{d}$, potentially digestible fraction $(\mathrm{g} / \mathrm{g}$ incubated $) ; f_{i}$, indigestible faction $(\mathrm{g} / \mathrm{g}$ incubated); $f_{s}$, soluble fraction $\left(\mathrm{g} / \mathrm{g}\right.$ incubated); $k_{h}$, fractional rate of hydration $(/ \mathrm{h}) ; k_{d}$, fractional rate of digestion $(/ \mathrm{h}) ; k_{r}$, fractional rate of bacterial detachment and /or cell lysis $(/ \mathrm{h})$.

* For details of substrates and procedures, see Table 1 and pp. 472-476.

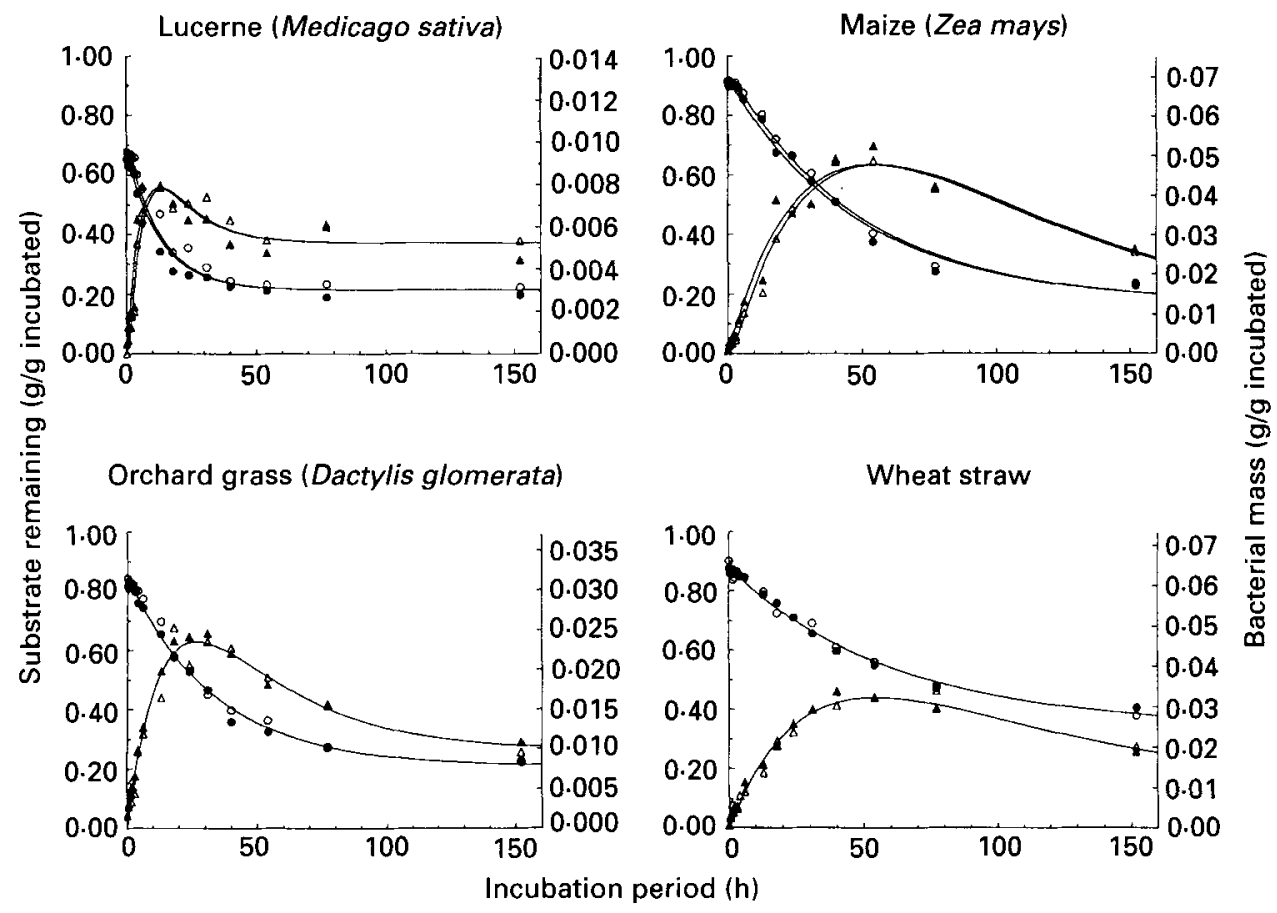

Fig. 2. Digestion and bacterial mass accumulation for lucerne (Medicago sativa), maize (Zea mays) cobs, orchard grass (Dactylis glomerata), and wheat straw. (O), dry matter (DM) remaining for dry substrate, (O), DM remaining for hydrated substrate; $(\triangle)$, bacterial DM mass originating from dry substrate; $(\boldsymbol{\Delta})$, bacterial DM mass originating from hydrated substrate. For details of substrates and procedures, see Table 1 and pp. $472-476$. 
Table 4. Parameter estimates describing changes in functional specific gravity of substrates*

(Non-linear estimates and their asymptotic standard errors)

\begin{tabular}{|c|c|c|c|c|c|c|c|c|}
\hline & \multicolumn{2}{|c|}{$\begin{array}{c}\text { Lucerne } \\
\text { (Medicago sativa) }\end{array}$} & \multicolumn{2}{|c|}{$\begin{array}{c}\text { Maize } \\
\text { (Zea mays) cobs }\end{array}$} & \multicolumn{2}{|c|}{$\begin{array}{c}\text { Orchard grass } \\
\text { (Dactylis glomerata) }\end{array}$} & \multicolumn{2}{|c|}{ Wheat straw } \\
\hline & Estimate & $\mathrm{SE}$ & Estimate & $\mathrm{SE}$ & Estimate & $\mathrm{SE}$ & Estimate & $\mathrm{SE}$ \\
\hline$A$ & 1.471 & 0.070 & $1 \cdot 278$ & 0.051 & 1.573 & 0.085 & 1.625 & 0.054 \\
\hline$B$ & $0 \cdot 721$ & 0.066 & 0.620 & 0.050 & 0.905 & 0.082 & 1.018 & $0-054$ \\
\hline$k_{F, S G}$ & $0-015$ & 0.003 & 0.025 & 0.005 & $0 \cdot 020$ & 0.004 & 0.028 & 0.004 \\
\hline
\end{tabular}

$A$, asymptotic functional specific gravity; $B$, potential change in functional specific gravity; $k_{F s G}$, fractional rate of change in functional specific gravity $(/ \mathrm{h})$.

* For details of substrates and procedures, see Table 1 and pp. 472-476.

\section{Functional specific gravity}

Parameter estimates describing the change in FSG are presented in Table $4 . k_{\mathrm{FSG}}$ was lowest for lucerne and highest for wheat straw. Moreover, these rates were much lower than $k_{h}$ estimated from substrate disappearance and bacterial mass accumulation (Table 3).

\section{DISCUSSION}

\section{Microbial contamination of substrate}

Fig. 3 illustrates the contamination of dry substrate by bacterial mass. Similar to findings shown in Fig. 3, Nocek \& Grant (1987) reported that microbial contamination tended to rise to a plateau or peak and then decline. However, these authors described bacterial contamination by linear or quadratic functions. The curves in Fig. 3 were obtained by dividing bacterial mass accumulation by the total residue (bacterial mass plus substrate remaining) as predicted by the models. $\mathrm{N}$ contamination was much higher than DM contamination, reaching up to $930 \mathrm{~g} / \mathrm{kg}$ for maize cobs. This was primarily due to the low $\mathrm{N}$ content of maize cobs $(4.8 \mathrm{~g} / \mathrm{kg})$ and the high $\mathrm{N}$ content of PAB $(81.9 \mathrm{~g} / \mathrm{kg})$.

Roger et al. (1990) reported that Ruminococcus flavefaciens adhered to cellulose in less than $1 \mathrm{~min}$. For Fibrobacter succinogenes, $80 \%$ of adherent cells adhered in $15-30 \mathrm{~min}$. In the present study, maximum bacterial attachment occurred between $4 \mathrm{~h}$ for lucerne and $55 \mathrm{~h}$ for both maize cobs and wheat straw (Fig. 2). The apparent discrepancy between these studies is due partially to the physical structure of the substrates. Substrates used for in vitro attachment studies with individual bacterial species are usually purified and finely ground or ball milled. Substrates used in the present study were ground through a $4 \mathrm{~mm}$ screen, which might be accompanied by a relatively small surface area available for bacterial attachment. It can be hypothesized that an increase in surface area is due primarily to microbial digestion of substrate. For example, digestion of a cell wall might be necessary to reach an adjacent cell. Therefore, maximal bacterial attachment might not be only a function of attachment properties of individual bacteria, but also a function of the digestion kinetics of the substrate.

\section{Digestion kinetics}

With the exception of maize cobs, digestion kinetic parameter estimates were similar for dry and hydrated substrate (Table 2). Theoretically, the difference between dry and hydrated substrate is hydration only, and no difference in fractionation of substrate was expected. 


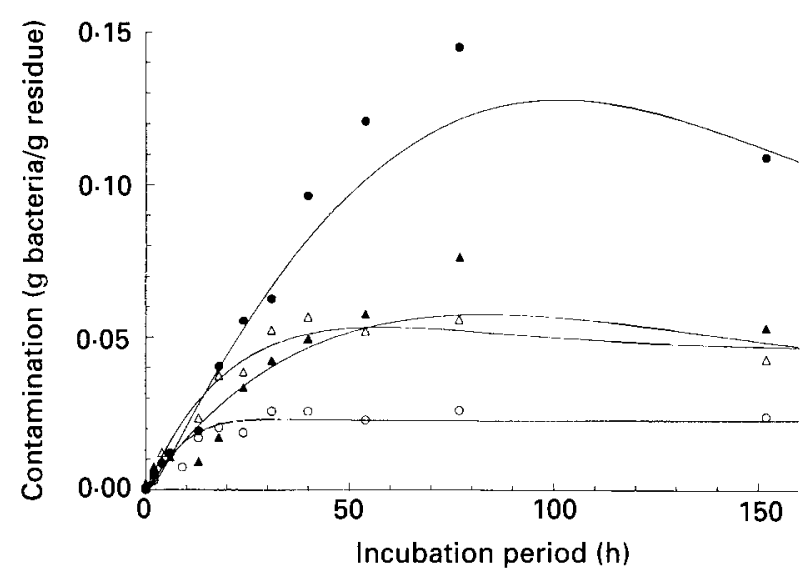

Fig. 3. Bacterial contamination of total residue during in situ rumen incubation. $(O)$, Lucerne (Medicago sativa) $(\mathbf{O})$, maize (Zea mays) cobs; $(\triangle)$, orchard grass (Dactylis glomerata); $(\mathbf{\Delta})$, wheat straw. For details of substrates and procedures, see Table 1 and pp. 473-477.

Cheng et al. (1980) reported that some damage to leaf plasmalemma occurred due to the presence of an incubation medium. However, it is expected that chemical or morphological changes that occurred during the hydration period occurred for dry substrate during rumen incubation as well. Differences in parameter estimates between dry and hydrated maize cobs might be due to the model that was used. No lag phenomena other than hydration were included, implying that digestion of hydrated substrate started instantaneously. Initial microbial attachment, enzyme synthesis and secretion also might have contributed to a delayed onset of digestion. In addition, parameter estimates are generally highly correlated in the estimation procedure, explaining the fact that not just one, but three of the four parameter estimates were different between dry and hydrated maize cobs.

A large percentage of $f_{d}$ resulted in production of end-products that did not remain associated with the substrate (Table 3 ). This percentage was considerably higher for lucerne (94) than for the other substrates (averaging 84) and might be due to a looser association of bacteria with lucerne. Cheng et al. (1980) reported that cell walls of legumes showed general disorganization after incubation with rumen bacteria, rather than specific pit structures shown for grasses. This disorganization might be the result of digestion by unbound microbial enzymes (Akin, 1986). Between 4.4 (lucerne) and 17.1\% (wheat straw) of $f_{d}$ was used for synthesis of temporarily attached bacteria. These bacteria attach to the part of $f_{a}$ that has not been digested yet and to $f_{i}$. As incubation proceeds, less substrate will be available for attachment whereas more bacteria will be synthesized (substrate is converted to bacterial mass). Although attachment is actually a surface phenomenon, it can be hypothesized that bacteria have to detach in order to survive. Not only will the nutrient supply diminish, but also the bacterial density on the substrate will increase. Cheng et al. (1991) reported that $F$. succinogenes adhered very intimately to cellulosic substrates, whereas $R$. albus maintained discrete spaces between cells.

Digestion end-products that are permanently associated with the remaining substrate represented less than $2 \%$ of $f_{d}$. Permanent association can occur only with the indigestible fraction as it is the only fraction that remains after infinite incubation. Attachment to $f_{d}$ can be explained easily by the fact that bacteria digest substrate. Attachment, then, results in close and prolonged proximity of bacterial digestive enzymes with the substrate. The $f_{i}$ is probably associated with $f_{d}$ and should not be considered a separate entity. As a result, attachment to $f_{i}$ could be the result of bacterial debris remaining from the period when 
potentially digestible material was present. If bacteria actually attach to $f_{i}$, this attachment should be either temporary or nutrients have to be provided by the rumen fluid.

Czerkawski (1986) has also used a compartmental approach to describe microbial populations using a rumen simulation technique (Rusitec). Compartments were defined as the quantity of microbes associated with liquid (compartment 1), loosely associated with substrate (compartment 2), or strongly associated with substrate (compartment 3) at a given time. Bags with different incubation periods were represented as different compartments. Because two bags with solid food are present at a given time, Czerkawski (1986) proposed that Rusitec should be described by a five-compartment model (two compartments 2 and 3 for each bag). Such a model only accounts for the spatial distribution of microbes, but gives little insight into the dynamics of this distribution. The double representation of compartments 2 and 3 could be eliminated by making the model more dynamic (i.e. by inclusion of time). The model proposed in the present study is a dynamic representation of compartment 3.

Hydration was not a major factor limiting digestion. Of the required hydration, $90 \%$ was fulfilled within $5 \mathrm{~h}$. For orchard grass and wheat straw, hydration did not appear to limit digestion at all. In contrast, $k_{F S G}$ was at least nineteen times smaller than $k_{h}$. This shows that hydration can have different biological interpretations. For example, it is likely that displacement of air by water affects the probability for passage, and this type of hydration is relatively slow. However, as shown in the present experiment, hydration is not a limitation to digestion. It is likely that water will start penetrating a plant particle at the (inner and outer) surfaces first. These are also parts that will be digested first. Thus, surfaces might be hydrated (and digestion commences) whereas vacuoles enclosed by these surfaces still contain large volumes of air. The high $k_{h}$ does not imply that there is no effect of drying on digestion kinetics. The $k_{h}$ represents the fractional rate of rehydration after the substrate was dried. Drying a substrate might have irreversible effects on digestion kinetics, which might not be overcome by rehydration.

The $k_{x}$ and $k_{d}$ were highest for lucerne and lowest for maize cobs and wheat straw (Table $3)$. This might be indicative of a looser association of bacteria on lucerne than on other substrates. Digestion of maize cobs and wheat straw apparently requires long and intimate contact of bacteria with the substrate. Akin (1986) reported that bacteria can degrade slowly-digestible tissues only after closely adhering to the cell walls.

\section{Conclusions}

The current model was developed in an attempt to integrate the processes of substrate disappearance and bacterial mass accumulation. It is shown that hydration is not a major limitation to digestion. Also, the dynamics and yields of PAB have been quantified for different substrates.

The technique of simultaneously analysing different, related phenomena allows the use of models involving many parameters. However, it should be realized that the current model is relatively simple and could be improved in many ways. For example, in the current model bacteria (with negligible mass) start to digest substrate, part of which is used for bacterial growth. Theoretically, one would assume that this increased bacterial mass would synthesize more enzymes and, thus, digest more substrate per unit time than the initial bacterial mass (autocatalysis), especially during the early hours of incubation. This implies an increasing rate of digestion, rather than a decreasing rate, as described by first-order kinetics. While digestion proceeds, substrate might become limiting or compounds inhibitory to bacterial growth might accumulate, depressing bacterial growth. In the proposed model, bacterial mass accumulation is only the result of substrate disappearance. However, as indicated previously, bacterial mass accumulation is the cause of digestion as 
well. A more thorough knowledge of microbial-substrate interrelations, as well as more complex statistical methods, would be required to analyse more detailed models of rumen digestion.

\section{REFERENCES}

Akin, D. E. (1986). Chemical and biological structures in plants as related to microbial degradation of forage cell walls. In Control of Digestion and Metabolism in Ruminants, pp. 139-157 [L. P. Milligan, W. L. Grovum and A. Dobson, editors]. Englewood Cliffs, NJ: Prentice-Hall.

Association of Official Analytical Chemists (1984). Official Methods of Analysis, 14th ed. Washington, DC: Association of Official Analytical Chemists.

Baldwin, R. L., Miller, P. S., Freetly, H. C., Hanigan, M. D., Fadel, J., Bowers, M. K. \& Calvert, C. C. (1990). Future of tissue level models. In Modelling Digestion and Metabolism in Farm Animals, pp. 345-357 [A. B. Robson and D. P. Poppi, editors]. Canterbury, New Zealand: Lincoln University.

Bremner, J. M. \& Mulvaney, C. S. (1982). Nitrogen - total. In Methods of Soil Analysis, Part 2. Chemical and Microbiological Properties. Agronomy Monographs no. 9, 2nd ed., pp. 595-624 [A. L. Page, editor]. Madison, WI : American Society of Agronomy Inc.

Cecava, M. J., Merchen, N. R., Berger, L. L., Mackie, R. I. \& Fahey, G. C. Jr (1991). Effects of dietary energy level and protein source on nutrient digestion and ruminal metabolism in steers. Journal of Animal Science 69, 2230-2243.

Cecava, M. J., Merchen, N. R., Gay, L. C. \& Berger, L. L. (1990). Composition of ruminal bacteria harvested from steers as influenced by dietary energy level, feeding frequency, and isolation techniques. Journal of Dairy Science 73, 2480-2488.

Cheng, K.-J., Fay, J. P., Howarth, R. E. \& Costerton, J. W. (1980). Sequence of events in the digestion of fresh legume leaves by rumen bacteria. Applied and Environmental Microbiology 40, 613-625.

Cheng, K.-J., McAllister, T. A., Kudo, H., Forsberg, C. W. \& Costerton, J. W. (1991). Microbial strategy in feed digestion. In Recent Advances on the Nutrition of Herbivores, pp. 181-187 [Y. W. Ho, H. K. Wong, N. Abdullah and Z. A. Tajuddin, editors]. Serdang, Malaysia: Malaysian Society of Animal Production.

Czerkawski, J. W. (1986). Degradation of solid feeds in the rumen: spatial distribution of microbial activity and its consequences. In Control of Digestion and Metabolism in Ruminants, pp. 158-172 [L. P. Milligan, W. L. Grovum and A. Dobson, editors]. Englewood Cliffs, NJ: Prentice-Hall.

Draper, R. N. \& Smith, H. (1981). Applied Regression Analysis, 2nd ed. New York, NY: John Wiley \& Sons, Inc.

Firkins, J. L., Berger, L. L., Merchen, N. R. \& Fahey, G. C. Jr (1986). Effects of forage particle size, level of feed intake and supplemental protein degradability on microbial protein synthesis and site of nutrient digestion in steers. Journal of Animal Science 62, 1081-1094.

France, J., Thornley, J. H. M., Dhanoa, M. S. \& Siddons, R. C. (1985). On the mathematics of digesta flow kinetics. Journal of Theoretical Biology 113, 743-758.

Goering, H. K. \& Van Soest, P. J. (1975). Forage Fiber Analyses (Apparatus, Reagents, Procedures, and Some Applications). Agriculture Handbook no. 379. Washington, DC: Agricultural Research Service, United States Department of Agriculture.

Hooper, A. P. \& Welch, J. G. (1985). Change of functional specific gravity of forage in various solutions. Journal of Dairy Science 68, 1652-1658.

Mulvaney, R. L., Fohringer, C. L., Bojan, V. J., Michlik, M. M. \& Herzog, L. F. (1990). A commercial system for automated nitrogen isotope-ratio analysis by the Rittenberg technique. Review of Scientific Instruments $\mathbf{6 1}$, $897-903$.

Nocek, J. E. \& Grant, A. L. (1987). Characterization of in situ nitrogen and fiber digestion and bacterial nitrogen contamination of hay crop forages preserved at different dry matter percentages. Journal of Animal Science 64, $552-564$.

Olubobokun, J, A. \& Craig, W. M. (1990). Quantity and characteristics of microorganisms associated with ruminal fluid or particles. Journal of Animal Science $\mathbf{6 8}, 3360-3370$.

Olubobokun, J. A., Craig, W. M. \& Pond, K. R. (1990). Effects of mastication and microbial contamination on ruminal in situ forage disappearance. Journal of Animal Science 68, 3371-3381.

Papageorgakopoulou, H. \& Maier, W. M. (1984). A new modeling technique and computer simulation of bacterial growth. Biotechnology and Bioengineering 26, 275-284.

Ratkowsky, D. A. (1983). Nonlinear Regression Modeling. New York, NY: Marcel Dekker.

Roger, V., Fonty, G., Komisarczuk-Bony, S. \& Gouet, P. (1990). Effects of physicochemical factors on the adhesion to cellulose Avicel of the ruminal bacteria Ruminococcus flavefaciens and Fibrobacter succinogenes subsp. succinogenes. Applied and Environmental Microbiology 56, 3081-3087.

SAS Institute Inc. (1988a). SAS/STAT User's Guide, release 6.03 ed. Cary, NC: SAS Institute Inc.

SAS Institute Inc. (1988b). SAS/ETS User's Guide, version 6. Cary, NC: SAS Institute Inc.

Thornley, J. H. M. \& France, J. (1984). Role of modeling in animal production research and extension work. In Modeling Ruminant Digestion and Metabolism. Proceedings of the Second International Workshop, pp. 4-9 [R. L. Baldwin and A.C. Bywater, editors]. Davis, CA: Department of Animal Science, University of California. 
Udén, P., Colucci, P. E. \& Van Soest, P. J. (1980). Investigation of chromium, cerium, and cobalt as markers in digesta. Rate of passage studies. Journal of the Science of Food and Agriculture 31, 625-632.

Van Milgen, J., Berger, L. L. \& Murphy, M. R. (1992). Fractionation of substrate as an intrinsic characteristic of feedstuffs fed to ruminants. Journal of Dairy Science 75, 124-131.

Van Milgen, J., Murphy, M. R. \& Berger, L. L. (1991). A compartmental model to analyze ruminal digestion. Journal of Dairy Science 74, 2515-2529. 